\title{
LIVER, KIDNEY FUNCTIONS AND OXIDATIVE STRESS STATUS AS AFFECTED BY SUPPLEMENTATION OF RED HOT PEPPER (CAPSICUM ANNUM) IN RATION OF FATTENING RABBIT'S
}

\author{
A.I. Zanouny and H.A.M. Elwan \\ Animal and Poultry Production Department, Faculty of Agriculture, Minia University, Egypt.
}

(Received 27/10/2017, accepted 11/12/2017)

SUMMARY

$\mathrm{T}$

This study was conducted to evaluate the effect of red hot pepper (RHP) as a natural antioxidant on liver, kidney functions and oxidative stress status of fattening rabbit's. A total of 48 New Zealand white rabbits, unsexed rabbits, 42 days-old, $1081.10 \pm 60.12 \mathrm{~g}$ were used in a complete randomized design. In this study rabbits were weighed individually and assigned randomly to three groups of 16 animals $/$ each with 8 replicates of 2 animals each. Three experimental diets were formulated to meet the nutrient requirements. Diet one served as control basal diet with no RHP, diet 2 and 3 supplement red hot pepper to the basal diet (RHP) at two levels (1 and 2\%), respectively. Also, the present results illustrated that rabbits fed $1 \%$ or $2 \%$ RHP had no significant effect on the values of live body weights at the end of the experimental period and also on absolute and relative liver and kidney weights compared to control dietary treatment. In addition, the studied parameters were; liver, kidney functions and some oxidative stress enzymes. The results showed that addition of 1and/or 2 RHP improved ( $\mathrm{P}<0.05)$ Alkaline phosphatase (ALP) activity compared to control group and at the same time1\%RHP decreased $(\mathrm{P}<0.05)$ serum urea and creatinine levels, while serum uric acid concentration increased $(\mathrm{P}<0.05)$ compared whit control group. Furthermore, addition of 1 and/or 2 RHP to rabbit diets increased $(\mathrm{P}<0.05)$ the activity of oxidative stress enzymes superoxide dismutase (SOD), catalase (CAT), glutathione-S-transferase (GST), glutathione (GSH) and malondialdehyde (MDA) compared with control group. This study showed that RHP when added into fattening rabbit diets has no adverse effects on liver and kidney functions and enhancing its oxidative stress. Also, the present result indicated that adding RHP had not any effect on serum total protein and albumin, while treatments $1 \%$ and or $2 \%$ led to highest $(\mathrm{P}<0.05)$ globulin levels compared with control group. Also, the results indicated that there were no effect of treatments on the structure of cells in liver or kidney. Generally, from the present results it can be concluded that supplementation of RHP at a level of $1 \%$ and $2 \%$ in the ration of fattening rabbit led to improvement of physiological responses as a result of positive effect on blood metabolites.

Keywords: red hot pepper, kidney function, oxidative stress, rabbits.

\section{INTRODUCTION}

There is evidence that vegetables and fruits plays a crucial role in regulating animal metabolism. Many literature indicated that importance of vegetables and fruits due to their high content of phytochemical active constituents. The genus Capsicum of the nightshade family (Solanaceae), including for example: Chili pepper (known as hot pepper), which including a number of species, such as Bell pepper, a Capsicum annuитcultivar, Datil pepper, a Capsicum chinense cultivar and Banana. Pungent spices, for example chili peppers, increase lipid catabolism in different organs and tissues (Lee et al., 2011 and Li et al 2012),reported that supplementation of peppers could protect against hypercholesterolemia and obesity, reducing the risks of hypertension, type 2 diabetes and atherosclerotic cardiovascular disease. The antimicrobial activity of spices, as highlighted by inhibitory effects against $H$. pylori and other bacteria and fungi (Lai and Roy 2004), may alter the gut micro- biota and influence various metabolic diseases (Tang $e t$ al., 2013 and Qin et al., 2014). Also,pepper is an extremely rich source of vitamin C and $\mathrm{E}$ (Lee et al., 2010). Red hot pepper (capsaicinoids) may have a stimulant, antiseptic and digestive effect due to capsaicin (Chevallier, 1996) which increases carbohydrate metabolism (Yoshioka et al., 1999). Abdo et al; 2003, Safa and Wahab 2014; Galibet al; 2011; Puvača et al (2014) and (2015) concluded that RHP improved growth performance of broilers and that decreased feed intake by using different RHP levels. Lee et al. (2010) reported that RHP enhanced local innate immunity and protection against Eimeriaacervulina infection. In another study, Hudaet al., (2015) concluded that, supplementation of $0.5,1$ and $1.5 \%$ hot red 


\section{Zanouny and Elwan}

pepper in the broiler diets resulted insignificant reduction in serum cholesterol compared to control group, while the levels of serum total protein, urea, ALP, calcium $(\mathrm{Ca})$ and phosphorus $(\mathrm{P})$ were remained unchanged. Previous study by (Lee et al., 2005) reported that phytochemical properties of capsaicinoids have shown many biochemical and pharmacological properties which includes antioxidant, antiinflammatory, antiallergenic and anti-carcinogenic activities. Surprisingly, the effects of red hot pepper have not been closely examined. Therefore, this study aims to investigated the effect of dietary RHP supplementation ( 1 and $2 \%$ of fattening rabbit diets) on liver, kidney functions and oxidative stress status of fattening rabbits.

\section{MATERIALS AND METHODS}

\section{Experimental design}

Rabbits were housed on the farm of Animal and Poultry Production Department, Faculty of Agriculture, Minia University in galvanized wire cages $(40 \times 50 \times 35 \mathrm{~cm})$, provided with feeders and automatic drinking water system, in a well-ventilated building and were kept under the same managerial, hygienic and environmental conditions. Feed and water were available all time ad libitum during the experimental period (56 days).

Red Hot Pepper (RHP)was provided from a private commercial market at El-Minya Governorate Egypt. Dried in the air oven on $70^{\circ} \mathrm{C}$ until constant weight. The dry RHP was finally milled, sieved (1 mm mesh) and stored in a well tight polyethylene bags at room temperature. Hot pepper powder was added and thoroughly hand mixed with the basal experimental diets.

Three batches of rabbits ration each of $180 \mathrm{~kg}$ were formulated to contain; $42 \%$ ground yellow corn, $40 \%$ wheat bran, $13.5 \%$ soybean meal (44\% crude protein), $0.5 \%$ limestone, $0.5 \%$ sodium chloride and $0.5 \%$ vitamin \& mineral premix and $3 \%$ vegetable oil.

In this experiment48 growing New Zealand White rabbits aged six weeks weighed in average $1081.10 \pm$ $60.12 \mathrm{~g}$ were randomly blocked by weight into three groups (16 animals each), where the $1^{\text {st }}$ group fed a basal ration free of hot pepper (control), while the $2^{\text {nd }}$ and $3^{\text {rd }}$ groups were fed on the same basal ration supplemented with dried red hot pepper at $1 \%$ and $2 \%$ levels, respectively. Basal ration was formulated to cover the nutrient requirement according to N.R.C (1977).

At the end of experiment period 10 representative rabbits randomly chosen from each group were fasted for $12 \mathrm{~h}$ before slaughtering according to Blasco et al. (1993), weighed and handily slaughtered and left complete bleeding. Slaughtered animals were de-skinned. liver and kidney weightswere recorded.

Relative liver and kidney weights values were calculated as present from the live body Weight.

\section{Physiological responses:}

\section{A-Biochemical blood parameters}

At the end of the experiment, $5 \mathrm{ml}$ blood samples were taken at 07:00 - 08:00 $\mathrm{h}$ am from each rabbit the marginal ear vein under vacuum in clean tubes before slaughtering time. Coagulated blood samples were centrifuged for 15 minutes at $5000 \mathrm{rpm}$ and the clear serum was separated and stored at $-20^{\circ} \mathrm{C}$ until biochemical analysis. Serum total protein content was determined according to the method of (Tietz, 1994). Serum albumin concentration was determined according to the method of (Tietz and Saunders, 1990). Serum globulin concentration and albumin /globulin $(\mathrm{A} / \mathrm{G})$ ratio were calculated using the following equations: -

Globulin $(\mathrm{gm} / \mathrm{dl})=$ Total proteins $(\mathrm{g} / \mathrm{dl})-$ Albumin $(\mathrm{g} / \mathrm{dl})$

Albumin /Globulin $(\mathrm{A} / \mathrm{G})$ ratio = Albumin $(\mathrm{g} / \mathrm{dl}) /$ Globulin $(\mathrm{g} / \mathrm{dl})$

Serum aspartate aminotransferase (AST) concentration was determined according to the method of (Tietz 1976). While, Serum alanine aminotransferase (ALT) concentration was determined according to the method of (Van der Sluijs et al 1992). Serum alkaline phosphatase (ALP) concentration was determined according to the method of (Tietz, 1986). Serum urea, uric acid and creatinine concentrations were determined according to the method of (Young,1990). The different previous blood parameters were determined by using commercial kits.

Also, blood serum were used to determine the activities of (SOD), (CAT), (GST) and(MDA) with an assay kits. One unit of SOD activity was defined as the amount of enzyme that inhibited auto-oxidation by $50 \%$ under the given experimental condition and the values were expressed as U/ml. CAT activity in blood serum was estimated by using $\mathrm{H}_{2} \mathrm{O}_{2}$ as a substrate with CAT assay kit and the absorbance was scanned at $405 \mathrm{~nm}$ by ultraviolet spectrophotometer. GST activity was determined by assaying the concentration of GSH with GST assay kit and the absorbance was scanned at $412 \mathrm{~nm}$ by ultraviolet spectrophotometer. The concentration of MDA a reliable marker of lipid peroxidation, was estimated in blood serum following the 
manual of MDA assay kit. Optical density was measured using an ultraviolet spectrophotometer at $532 \mathrm{~nm}$ against blanks prepared by using distilled water. The activities of SOD, CAT and GST and the level of MDA were calculated from the resulting absorbance values. Estimation of GST, CAT, SOD, GSH and MDA were done according to Habig et al., 1974, Clairborne,1985, Kakkar et al., 1984, Ellman, 1959 and Jain et al., 1989, respectively.

\section{B-Histopathological examinations}

Microscopic changes were observed through random selection of liver and kidney samples from each treatments and control animal groups. Tissues were preserved in $10 \%$ formalin followed by dehydration in ascending grades of alcohol. Clearing by xylene and embedding in paraffin wax. Paraffin sections $(5 \mu \mathrm{m}$ thickness) were stained with hematoxylin and eosin (H \& E) for histological examination.

Statistical analysis

The data were analyzed by one-way ANOVA and Duncan's multiple range test using the SAS software (Statistical analysis system (SAS), version 9.1.3, 2003) to test the statistically significant differences between the treatments.

\section{RESULTS AND DISCUSSION}

\section{1-Live body, liver and kidney weights}

Data presented in Table (1), revealed that rabbits fed 1\% or 2\% RHP had no significant effect on the values of live body weights at the end of the experimental period and also on absolute and relative liver and kidney weights compared to control dietary treatment. This result disagreed with the finding of Safa and Wahab (2014) who reported that, the inclusion of different mixture powder levels of red and black peppers significantly $(\mathrm{P}<0.05)$ improved the percentages of liver and gizzard with exception of the heart percentage which was in significant.

Table (1): \% Red hot pepper (RHP) supplementation.

\begin{tabular}{lcccc}
\hline Item & Control & RHP 1\% & RHP 2\% & Probability \\
\hline Live body weight & $2025.66 \pm 46.09$ & $2040.66 \pm 59.851$ & $2068.68 \pm 24.34$ & $(\mathrm{P}=0.793)^{\mathrm{NS}}$ \\
Liver weight & $52.033 \pm 4.23$ & $47.600 \pm 3.591$ & $47.500 \pm 6.353$ & $(\mathrm{P}=0.763)^{\mathrm{NS}}$ \\
Liver \% & $2.566 \pm 0.177$ & $2.328 \pm 0.130$ & $2.290 \pm 0.278$ & $(\mathrm{P}=0.613)^{\mathrm{NS}}$ \\
Kidney Weight & $13.00 \pm 1.767$ & $11.737 \pm 0.690$ & $12.633 \pm 1.656$ & $(\mathrm{P}=0.824)^{\mathrm{NS}}$ \\
Kidney \% & $0.675 \pm 0.055$ & $0.574 \pm 0.0219$ & $0.678 \pm 0.0402$ & $(\mathrm{P}=0.213)^{\mathrm{NS}}$ \\
\hline
\end{tabular}

RHP= Red Hot Pepper NS= Not significant

\section{2- Biochemical blood parameters}

Data of liver and kidney function illustrated in Table (2). The present results i indicated that adding RHP to fattening rabbit diet hadn't any effect on serum total protein and albumin compared to control group. Moreover, rabbits of 1 and/ or $2 \%$ RHP had the highest $(\mathrm{P}<0.05)$ globulin levels compared to control group. Thus, AB/GL ratio decreased $(\mathrm{P}<0.05)$ whit RHP addition when compared to control group. The results in Table $(2$ indicated that rabbits fed on 1 and $2 \%$ RHP had the highest $(\mathrm{P}<0.01)$ or $(\mathrm{P}<0.05)$ values of ALT, AST and ALP in comparison with control group. Moreover, rabbits fed on the highest RHP level $(2 \%)$ recorded the highest $(\mathrm{P}<0.05)$ concentration of creatinine and urea compared to other groups. Contrary, the lowest RHP supplementation had the highest uric acid concentration in comparison with other groups. Whereas, addition of 1 RHP to fattening rabbit diet decreased $(\mathrm{P}<0.05)$ the level of creatinine and urea compared to other groups. The result coincided with the finding of El-Husseiny et al., (2002) found that broiler chicks fed of hot pepper tothe dietary doses of 1, 1.5 and $2 \%$ had no any significant effect on this parameters. Goncalves et al., (2012) studied the effect of Brazilian red pepper meal $(\mathrm{BRPM})$ at 21 days of age on liver function. They reported that, there were increased $(\mathrm{P}<0.05)$ the levels of aspartate aminotransferase and decreased alanine aminotransferase in broilers supplemented with 
BRPM. Moreover, there were no significant effect $(\mathrm{P}>0.05)$ of treatments on broilers weight and relative liver weight at 43 days of age.

Table (2): Liver and kidney functions as affected by 0,1 and $2 \%$ red hot pepper supplementation.

\begin{tabular}{lcccc}
\hline Item & Control & RHP 1\% & RHP 2\% & Probability \\
\hline Total Protein( & $6.251 \pm 0.149$ & $6.319 \pm 0.059$ & $6.440 \pm 0.113$ & $(\mathrm{P}=0.524)^{\mathrm{NS}}$ \\
Albumin(AB) & $4.283 \pm 0.0957$ & $3.806 \pm 0.120$ & $3.898 \pm 0.238$ & $(\mathrm{P}=0.171)^{\mathrm{NS}}$ \\
Globulin(GL) & $1.967 \pm 0.120^{\mathrm{b}}$ & $2.513 \pm 0.121^{\mathrm{a}}$ & $2.542 \pm 0.165^{\mathrm{a}}$ & $(\mathrm{P}=0.042)^{*}$ \\
AB/GL ratio & $2.195 \pm 0.151^{\mathrm{a}}$ & $1.525 \pm 0.112^{\mathrm{b}}$ & $1.559 \pm 0.201^{\mathrm{b}}$ & $(\mathrm{P}=0.042)^{*}$ \\
AST & $41.624 \pm 0.099^{\mathrm{b}}$ & $41.739 \pm 0.152^{\mathrm{a}}$ & $43.573 \pm 0.152^{\mathrm{a}}$ & $(\mathrm{P}=0.001)^{* *}$ \\
ALT & $108.608 \pm 0.732^{\mathrm{b}}$ & $111.512 \pm 0.302^{\mathrm{a}}$ & $110.561 \pm 0.721^{\mathrm{a}}$ & $(\mathrm{P}=0.041)^{*}$ \\
ALP & $10.440 \pm 0.172^{\mathrm{b}}$ & $11.783 \pm 1.683^{\mathrm{a}}$ & $16.833 \pm 1.683^{\mathrm{a}}$ & $(\mathrm{P}=0.037)^{*}$ \\
Creatinine & $2.030 \pm 0.0115^{\mathrm{b}}$ & $1.510 \pm 0.0115^{\mathrm{c}}$ & $2.250 \pm 0.0057^{\mathrm{a}}$ & $(\mathrm{P}=0.001)^{* *}$ \\
Urea & $51.239 \pm 4.210^{\mathrm{b}}$ & $41.702 \pm 0.163^{\mathrm{c}}$ & $62.564 \pm 0.148^{\mathrm{a}}$ & $(\mathrm{P}=0.03)^{*}$ \\
Uric acid & $3.394 \pm 0.0464^{\mathrm{b}}$ & $4.036 \pm 0.0464^{\mathrm{a}}$ & $3.340 \pm 0.0966^{\mathrm{c}}$ & $(\mathrm{P}=0.01)^{* *}$ \\
\hline
\end{tabular}

NS= Not significant

$a, b$ and $c$ Values within a row with different superscripts differ significantly at $(P<0.05) \operatorname{or}(P<0.01)$

$A S T=$ Aspartate aminotransferase $-A L T=$ Alanine aminotransferase-ALP=Alkaline phosphatase,

Oxidative stress enzymes (SOD, CAT, GST and MDA) had an important role in protection against the effects of free radicals. The main oxidative stress enzymes, superoxide dismutase. Moreover, malondialdehyde (MDA) play an imported role as a reliable marker of lipid peroxidation in the cells. As indicated in Table (3), there were a significantly $(P<0.01)$ increased in SOD, GSH, GST and CAT values of RHP supplementation in comparison with control group. Also, it can be seen that; the addition of 1 $\%$ RHP was sharply increased the activity of SOD, GSH, GST and CAT by $59.11,10.65,6.13$ and $9.88 \%$, respectively compared to control group, whereas the addition of 2 RHP recorded the highest values of oxidative stress enzymes in comparison with other groups. Contrary, the addition of RHP to fattening rabbit diet decreased $(\mathrm{P}<0.001)$ malondialdehyde $(\mathrm{MDA})$ levels compared to control group. Taken together, these results suggest that there isan association between red hot pepper addition and rabbit physiological responses. Oxidative stress is defined as a misbalance in cell redox reactions resulting in the increase of reactive oxygen species (ROS) and/or decreased antioxidant defense. Crucial part of oxidative stress, which avoids protective effects of antioxidants is lipid peroxidation.

Table (3): Serum oxidative stress enzymes status as affected by 0,1 and $2 \%$ red hot pepper supplementation.

\begin{tabular}{|c|c|c|c|c|}
\hline Item & Control & RHP $1 \%$ & RHP $2 \%$ & Probability \\
\hline $\mathrm{SOD}(\mathrm{U} / \mathrm{ml})$ & $1.793 \pm 0.0636^{\mathrm{c}}$ & $2.853 \pm 0.0636^{b}$ & $3.183 \pm 0.0874^{\mathrm{a}}$ & $(\mathrm{P}=0.001)^{* *}$ \\
\hline $\mathrm{GSH}(\mu \mathrm{mol} / \mathrm{L})$ & $0.657 \pm 0.0578^{c}$ & $0.727 \pm 0.0291^{\mathrm{b}}$ & $0.817 \pm 0.049^{\mathrm{a}}$ & $(\mathrm{P}=0.001)^{* *}$ \\
\hline GST(U/ml) & $66.81 \pm 0.495^{\mathrm{c}}$ & $70.91 \pm 0.386^{\mathrm{b}}$ & $72.66 \pm 0.326^{\mathrm{a}}$ & $(\mathrm{P}=0.001)^{* *}$ \\
\hline CAT (U/ml) & $20.063 \pm 0.0742^{c}$ & $22.047 \pm 0.108^{\mathrm{b}}$ & $23.600 \pm 0.340^{\mathrm{a}}$ & $(\mathrm{P}=0.001)^{* *}$ \\
\hline $\operatorname{MDA}(\mu \mathrm{mol} / \mathrm{L})$ & $3.027 \pm 0.118^{\mathrm{a}}$ & $2.370 \pm 0.077^{\mathrm{b}}$ & $1.640 \pm 0.0416^{\mathrm{c}}$ & $(\mathrm{P}=0.001)^{* *}$ \\
\hline
\end{tabular}

Superoxide dismutases (SOD) are the first line of defense against superoxide anions. SOD catalyses disproportion of superoxide anion to hydrogen peroxide and molecular oxygen. Hydrogen peroxide, generated by SOD, still represents a danger for the cell and is therefore, substrate for another enzyme 
catalase. Catalase decomposes hydrogen peroxide in two ways: one acting as catalyst with water and oxygen as end products, and other acting as peroxidase. Catalase is one of the most efficient enzyme, with reaction rate limited by the collision rate of enzyme with substrate. Glutathione (GSH) is one of the most iquitary small molecules of antioxidant defence (Michiels et al., 1994).

\section{3-Histological alterations}

The basic structure of liver and kidney (Fig1) and (Fig2) sections stained with H\&E stain showed numerous hepatic lobules. Fig. 1 (A, B and C )illustrated that, the central vein is located in the middle of the lobule. The hepatocytes are polygonal in shape with granulated, eosinophilic cytoplasm and centrally located nuclei with one or two nucleoli and delicate strands of chromatin. Also, Kupffer cells appeared between the hepatocytes as spindle-shaped cells

Fig. 2 (A, B and C) illustrated that, the kidney consists of an outer cortex and an inner medulla. The outer cortex of control kidneys contains the renal corpuscles which appear as large spherical structure and renal tubules (proximal and distal convoluted tubules). Each renal corpuscle is surrounded by the Bowman's capsule composed of simple squamous epithelial cells. It encloses the urinary space and the capillary tuft of the glomerulus which consists of blood capillaries.

From histological examination it can be concluded that there were no adverse effect of various treatments on the structure of different cells in liver or kidney as result of supplementation of hot pepper in the ration of fattening rabbits.
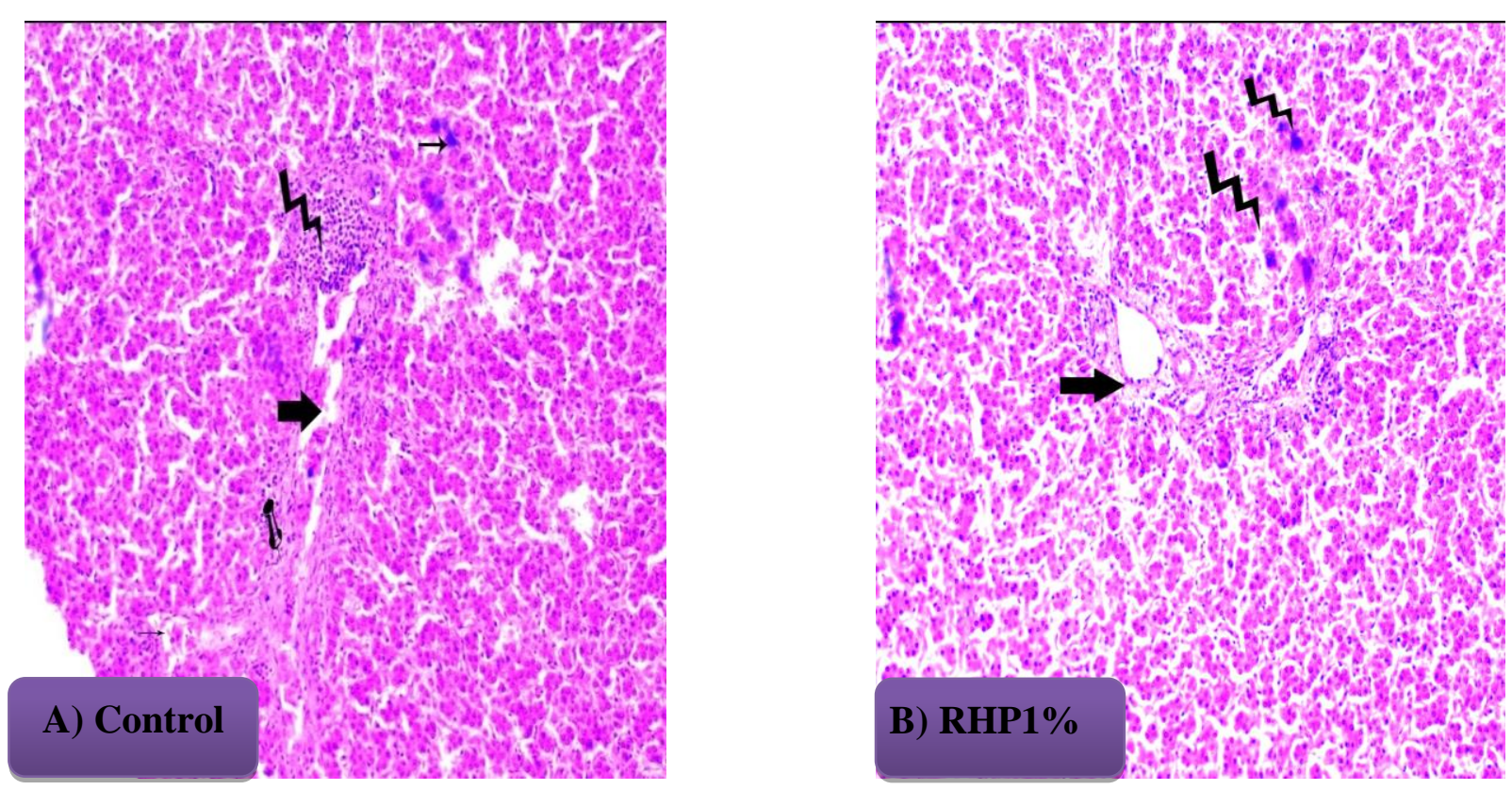


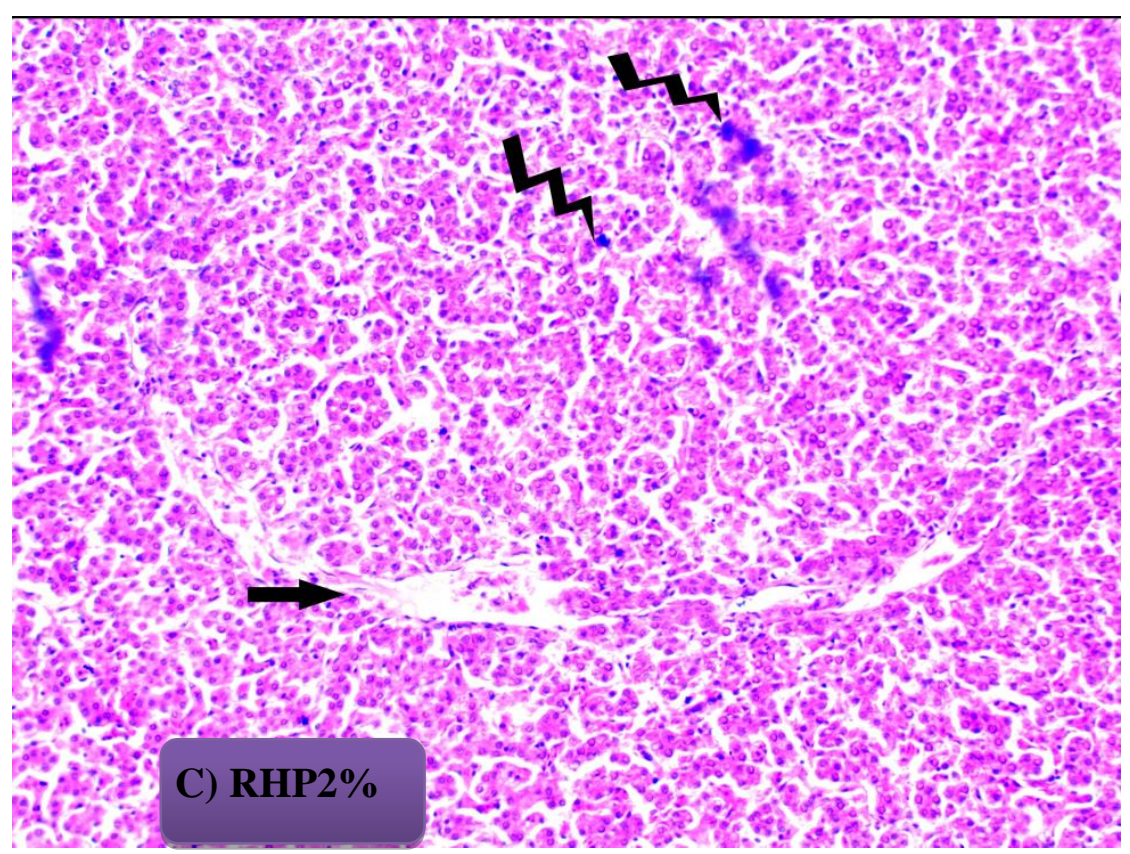

Figure (1). Photomicrograph of liver sections (A, B and C) showing normal histological structure; with filtrated white blood cells zigzag arrow and vacuolations pin arrow and pyknotic nuclei(A; control)pyknotic nuclei zigzag arrow (B;RHP1\% and C; RHP2\%). Stained with general stain (H\&E).
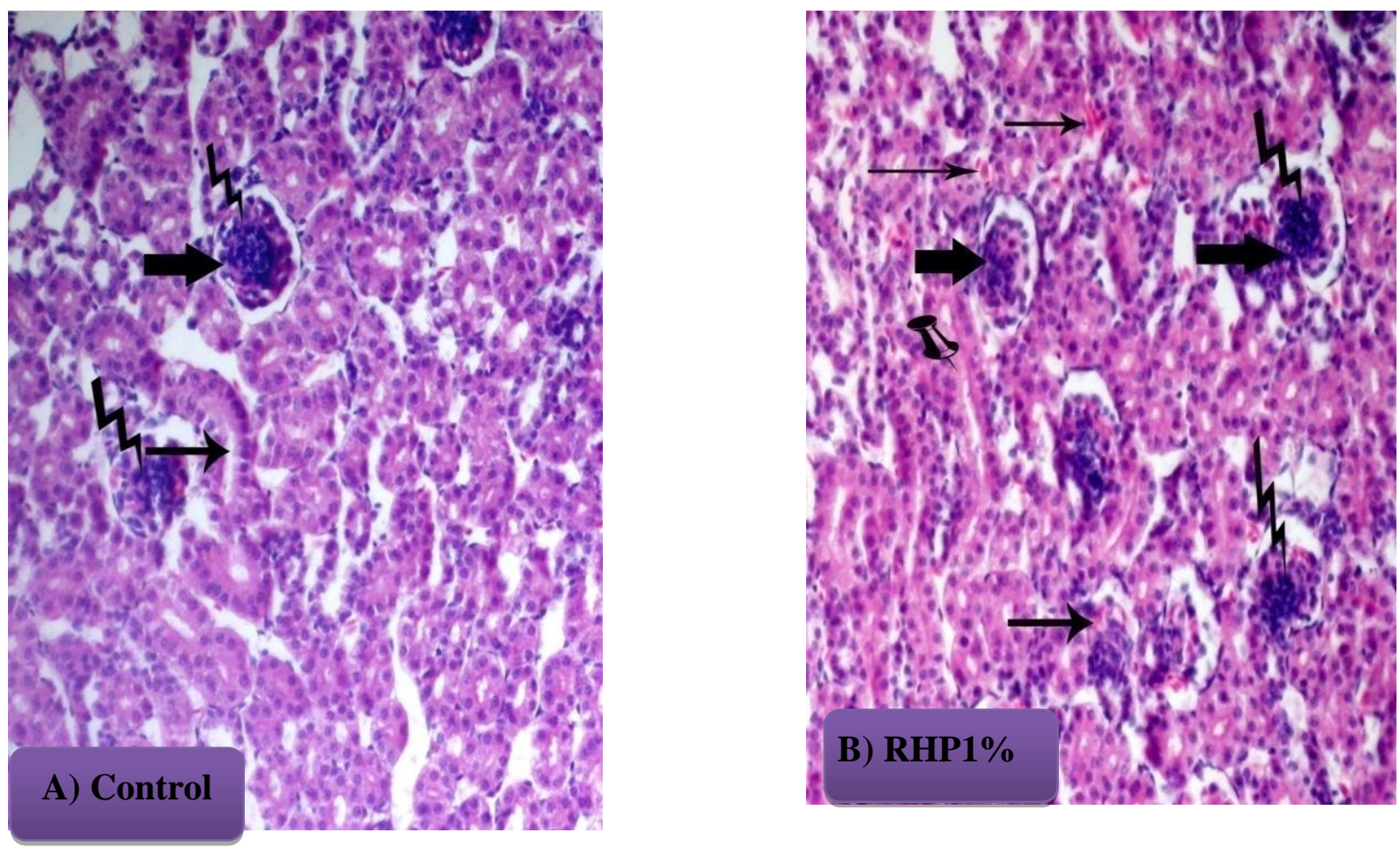


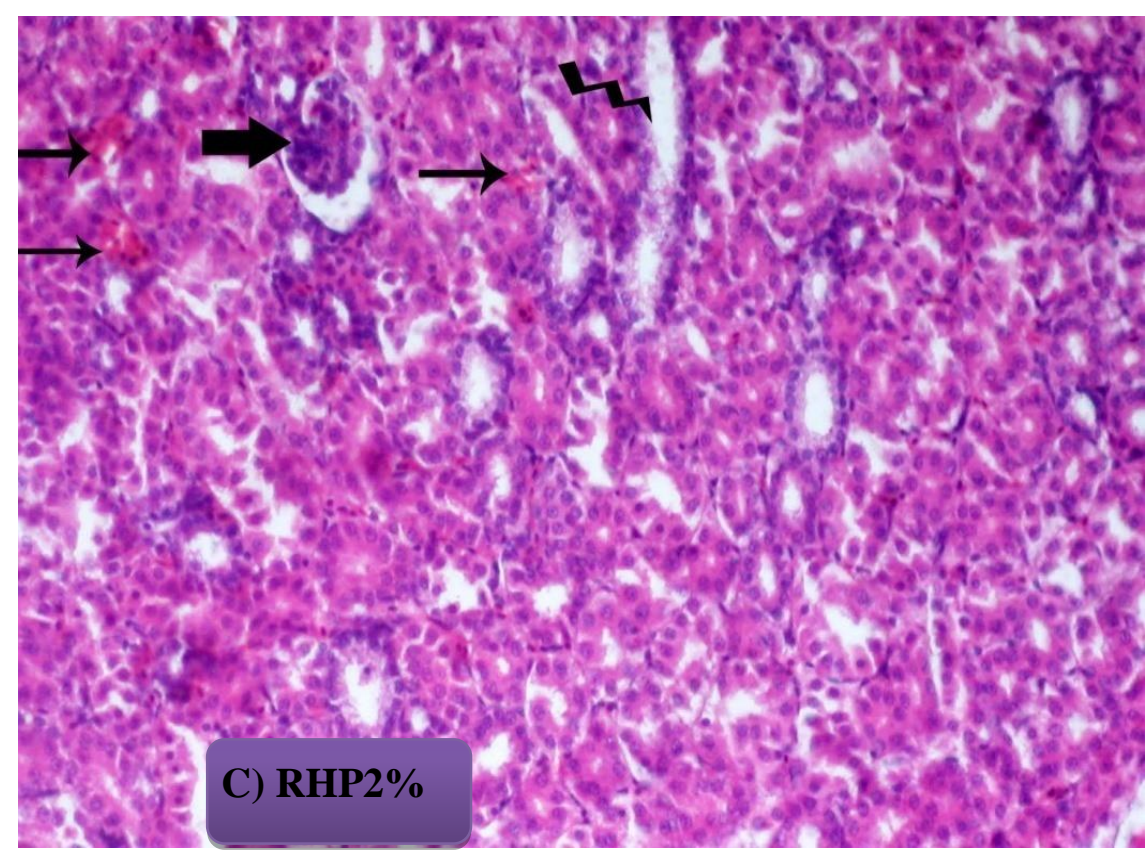

Figure (2). Photomicrograph of kidney sections (A, B and C) showing normal histological structure and glomerulus capsule; dilated in urinary space and pyknotic nucleizigzag arrow (A; control) pyknotic nuclei zigzag arrow, dilated in urinary space pin arrow and hemorrhage (B;RHP1\% and C; RHP2\%). stained with general stain (H\&E).

\section{CONCLUSION}

Under the conditions of the present study, it could be concluded that inclusion of hot pepper in fattening rabbit diets as a natural antioxidantis highly recommended to enhance rabbit liver, kidney functions and oxidative stress status.Also, the results indicated that there were no effect of treatments on the structure of cells in liver or kidney. The best results were achieved with $1 \%$ hot pepper. However, there were no adverse effects were occurring with $2 \%$ hot pepper supplementation for all measured parameters.

\section{REFERENCES}

Abdo, Z.M.A.; A.Z.M. Soliman.; Barakat, Olfat S. (2003). Effect of HP and marjoram as feed additives on the growth performance and the microbial population of the gastrointestinal tract of broilers. Egyptian Poult. Sci. J. 23, 91-113.

Blasco, A.; J. Quhayaun and G. Masoscro. (1993). Harmonization of criteria and terminology in rabbit meat research. World Rabbits Sciences, 1: 3-10.

Chevallier, A. (1996). The encyclopedia of medicinal plants Published by DK Publishing Inc., USA.

Clairborne, A. (1985). Catalase activity. In: Handbook of methods for oxygen radical research (R. A. Greenwald, Ed). Boca Raton, FL, pp. 283-284

Duncan, D. B. (1955). Multiple range and multiple F-test. Biometrics, 11: 1-42

El Husseiny, O.; S.M. Shalash, and H.M. Azouz (2002). Response of broiler performance to diets containing hot pepper and/or fenugreek at different metabolizable energy level. Egypt Poult. Sci. (11): 387-406.

Ellman, G.L. (1959). Tissue sulfhydryl groups. Arch Biochem. Biophys., 82: 70-77.

Galib, A.M.; Al-Kassie, M.; Al-Nasrawi, A.M. and J.A. Saba (2011). The effects of using hot red pepper as a diet supplement on some performance traits in broiler. Pakistan Journal of Nutrition 10: 842-845. 


\section{Zanouny and Elwan}

Goncalves, F.G ; S.F. Zanini, M.L. Feitosa, E.P.M. Goncalves and G.L Colnago (2012). Effect of Brazilian red pepper meal associated with different levels of antibiotics on broilers chickens. Ciencia Rural 42: 1503-1509.

Habig, W. H.; M. J. Pabst, and W. B. Jacoby, (1974). Glutathione S-transferases: the first enzymatic step in mercapturic acid formation. J. Biol. Chem., 249:7130-7139.

Huda, M. S; K.A. Mohamed and M.A Mukhtar. (2015). Effect of hot red pepper (Cspsiciumfrutescens)on performance, abdominal fat and blood serum parameters of broiler.Journal of Global Biosciences. Volume 4, Number 5, pp. 2251-2257

Jain SK; R McVie, J. Duett and J.J. Herbst (1989). Erythrocyte membrane lipid peroxidation and glycocylated hemoglobin in diabetes. Diabetes; 38: 1539-1543.

Kakkar, P.; B. Das and P.N. Viswanathan (1984). A modified spectrophotometric assay of superoxide dimutase. Indian J. Biochem. Bio. Phys. 21, 130-132.

Lai, P.K. and J. Roy (2004). Antimicrobial and chemopreventive properties of herbs and spices. Current medicinal chemistry11(11):1451-1460.

Lee, M.S.; C.T. Kim, I.H. Kim and Y. Kim (2011). Effects of capsaicin on lipid catabolism in 3T3-L1 adipocytes. Phytotherapy research: PTR 25(6):935-9.

Lee, J..J; K..M Crosby,.; L.M Pike,.; K.S. Yoo, and D.I. Lescobar, (2005). Impact of genetic and environmental variation of development offlavonoids and carotenoids in pepper (Capsicum spp.). Scientia Horticulturae 106: 341-352.

Lee, S.H.; H.S. Lillehoj; S.I.K. Jang; D.K. Kim; C. Ionescu, and D. Bravo (2010): Effect of dietary Curcuma, capsicum, and lentinus on enhancing local immunity against, Eimeria a Cevilian infection. The J. of Poult. Sci. 47, 89-95

Li, L.; J. Chen, Y. Ni; X. Feng, Z. Zhao and P. Wang (2012). TRPV1 activation prevents nonalcoholic fatty liver through UCP2 upregulation in mice. Pflugers Archiv: European journal of physiology 463(5):72732.

Michiels, C., M. Raes; O. Toussaint and J. Remacle (1994). Importance of SE-glutathione peroxidase, catalase, and CU/ZN-SOD for cell survival against oxidative stress. Free RadicBiol Med 17: 235-248

N.R.C. (1977). National Research Council. Nutrient Requirements of Rabbits, National Academy of Science, Washington, D.C, USA.

Puvača, N.; D. Ljubojević; Lj. Kostadinović; J,Lević; N, Nikolova; B. Miščević; T. Könyves; D, Lukač And S, Popović. (2015). Spices and herbs in broilers nutrition: hot red pepper (Capsicum annuumL.) and its mode of action. World's Poultry Science Journal, Vol. 71; 683-688.

Puvača, N; D. Ljubojević,; D. Lukač,; , L.J. Kostadinović; V. Stanaćev,; S .Popović,; M. ŽivkovBaloš, and N. Nikolova, (2014) Digestibility of fat in broiler chickens influenced by dietary addition of spice herbs.Macedonian Journal of Animal Science4: 61-67.

Qin N, F.Yang,; A. Li;, E. Prifti; Y.Chen and L. Shao (2014). Alterations of the human gut microbiome in liver cirrhosis. Nature. 513(7516):59-64.

Safa M. A. and W. El-Tazi (2014), Response of Broiler Chicken to Diets Containing Different Mixture Powder Levels of Red Pepper and Black Pepper as Natural Feed Additive. Animal and Veterinary Sciences; 2(3): 81-86.

SAS (2003). Institute. Inc. SAS/STAT user's guide: Statistics (versin6.4th ed.) Vol.2. SAS Insitute.Inc. Cary. NC. 2003.

Tietz, NW. (1976): Fundamentals of clinical chemistry. W.B. saunders Co., Philadelphia, p.1028.

Tietz, N. W., (1986). textbook of clinical chemistry. W. B. Saunders, Philadelphia, p 1271- 1281.

Tietz, N.W. (1994). Fundamentals of Clinical Chemistry. 2nd Edn., WB Saunders, Philadelphia, pp: 692.

Tietz, N. W., and W.B. Saunders (1990). Clinical Guide to Laboratory tests: $2^{\text {nd }}$ ed. Philadelphia: 26-29.

Van der Sluijs, P.; M..Hull; P. Webster; P. Male; B. Goud, and I. Mellman (1992). The small GTPbinding protein rab4 controls an early sorting event on the endocytic pathway. Cell 70, 729-740 
Yoshioka, M; S.S. Pierre; V. Drapeau; I. Dionne; E. Doucet; M. Suzuki and A. Tremblay (1999) Effects of red pepper on appetite and energy intake. Br. J. of Nut. 82, 115-123.

Young, D.S. (1990). Effects of drugs on clinical laboratory tests. $3^{\text {rd }}$ ed. 6-12

$$
\text { وظائف الكبد والكلي وحالة الاجهاد التاكسدي وتاثرها باستخدام الفلفل الاحمر الحارفي علائق ارانب التسمين }
$$

\section{عبدالرحمن ابراهيم زنونى و حمادة عبدالحميد مهنى علوان \\ قسم الإنتاج الحيوانى والد/جنس- كلية/لزراعة - جامعة/لكنيا}

أجريت هذه الدراسة لتقييم تأثير الفلفل الحار الأحمر كمضاد للأكسدة الطبيعية على وظائف الكبد والكلى وحالة الإجهاد التأكسدي

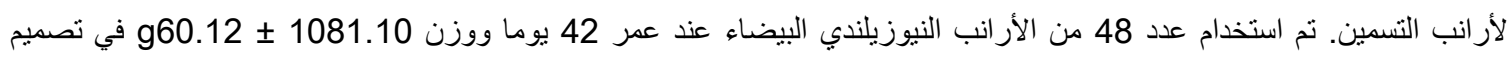

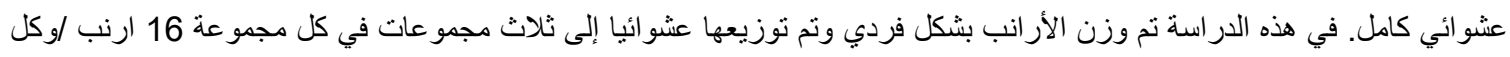

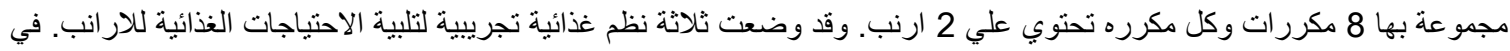

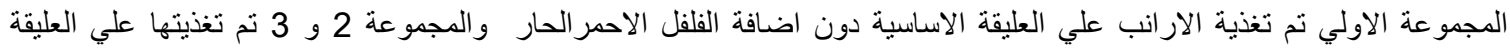

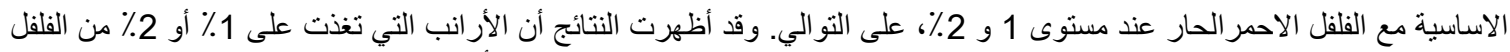

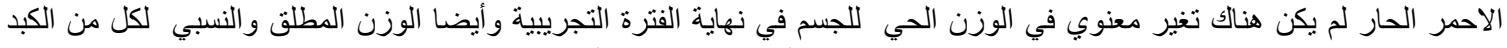

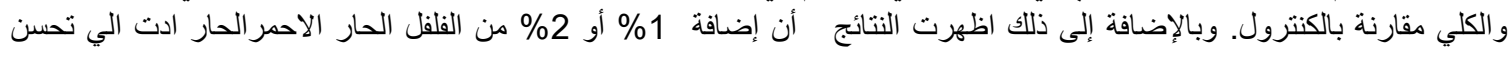

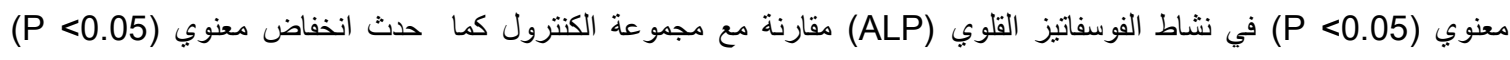

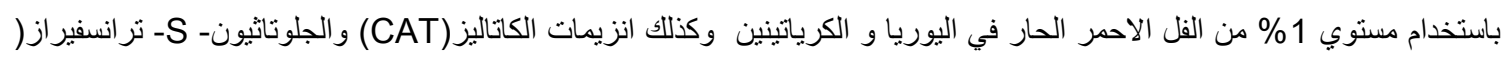
و الجلوناثيون مالونديالدهيد (GST) مقارنة مع مجموعة الكنترول. و أظهرت هذه الدراسة أنه عند اضافة 1 \% و و 2.

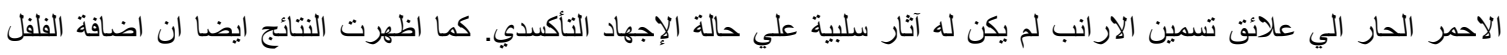

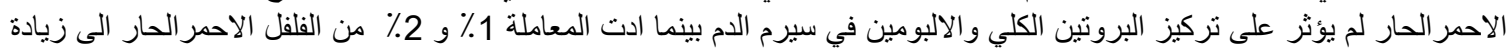

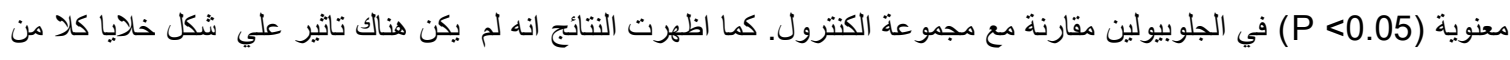

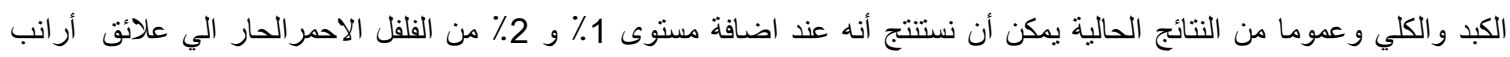
التسمين أدى إلى تحسن في الاستجابات الفسيولوجية نتيجة للتأثير الإيجابي على نواتج التهن التمثيل الغذائي للجسم. 